\title{
SANITARY, EDUCATIONAL, AND TOWN-PLANNING LEGISLATION OF UKRAINE ON ENSURING THE VITAL ACTIVITY FUNCTION CONDITIONS IN THE PUPILS AT SCHOOLS: WORLD EXPERIENCE, UKRAINIAN REALITIES AND PROSPECTS
}

\author{
Makhniuk V. M., Pavlenko N. P.
}

\section{INTRODUCTION}

Introduced in September 2017, the education reform began with the adoption of the new Law on Education, which regulates the basic principles of the new educational system. In February 2018, the Cabinet of Ministers approved a new State Standard for Primary Education. The new law on general secondary education reveals changes introduced by the reform in more details. The new Standard of Primary Education, namely the New Ukrainian School (NUS) provides a 12-year term of study, educational innovations: personality-centered and competent approaches to learning, requires the creation of a new educational space, which is extremely difficult on the basis of existing schools ${ }^{1,2,3}$.

Analyzing demographic parameters, it was found that since 2010, the population growth in Ukraine has increased in comparison with previous years. According to the State Statistics Service of Ukraine at the beginning of 2018-2019, the number of children aged six years increased by $25 \%$ and made up about 3012.000 people, which requires additional places in the GSEI, which can be provided by means of the construction of new educational institutions ${ }^{4,5,6,7}$.

${ }^{1}$ Serdyuk A.M., Polka N.S., Makhnyuk V.M. Modern problems of hygiene of planning and building of settlements (normative-legal regulation) : monograph. K. : MIC "Medinform", 2014. 174 p.

${ }^{2}$ Mental capacity, educational load and way of life of modern schoolchildren: hygienic aspects : monograph / N.S. Polka, S.V. Gozak, O.T. Elizarova, A.M. Parats, T.V. Stankevich, I.O. Kalinichenko, G.L. Zaikina, G.O. Latina ; ed. N.S. Polki, S.V. Gozak. Kyiv: Medinform, 2018. 214 p. P. $185-210$.

3 Pavlenko N.P., Makhnyuk V.M., Gozak S.V. Sanitary and hygienic conditions for children in existing and projected secondary schools of Ukraine. Hygiene of populated places : collection. science. pr. K., 2017. Vip. 66. P. 228-235.

4 "Hygiene and ecology in state regulation of urban planning". Edited by the corresponding member of NAMS of Ukraine N.S. Polky / V.M. Machniuk, V.G. Hopperia, O.O. Polka, N.P. Pavlenko, G.V. Ocheretyana. Publisher : IEC “Medinform”, 2020. 170 p.

5 Demographic and social statistics. Population and migration. State Statistics Service. 2020. URL: http://www.ukrstat.gov.ua/operativ/menu/menu_u/ds.htm.

${ }_{7}^{6}$ Demographic trends in Ukraine. URL: http://rb.com.ua/rus/marketing/tendency/8227/. Demographic and social statistics / Education. URL: http://www.ukrstat.gov.ua/operativ/menu/menu_u/osv.htm. 
Early start of systematic education in the GSEI, new educational programs and pedagogical technologies without hygienic support, lack of systematic medical care under school conditions is a trial for the child's organism, its physical and social maturity, especially for the children of primary school age. At the same time, the analysis of statistical data and the results of scientific research indicate a significant increase in the incidence among schoolchildren, the transition from acute to chronic diseases, and as a result - the formation of expressed "school" pathology. Ukrainian and foreign scientists are thoroughly researching secondary schools from the standpoint of conducting and improving the educational process and its impact on the health of the pupils. However, the issue of design and construction of these institutions (especially the availability of the sufficient land for the arragement of school territory, rational planning of all premises of the standard area, providing premises with natural light and insolation, etc.) remains out of the attention of the Ukrainian scientists ${ }^{8,9,10,11}$. Thus, the lack of the studies on the planning solutions, king into account the creation of optimal conditions for the vital activity of the children of primary school in Ukraine, stipulated the urgency of the work.

The aim of the work was to substantiate the hygienic criteria for architectural- and-planning decisions of the educational space to ensure the sanitary-and- epidemiological conditions of the vital activity of primary school pupils, taking into account foreign experience.

The subject of the study was a set of hygienic parameters of architectural- and- planning decisions for the creation of safe and comfortable conditions of the stay of primary school pupils at the institutions of general secondary education; health-preserving component in the standard-legal framework of GSEI design.

To implement the tasks we used a set of general and special research methods: bibliosemantic, analytical, sanitary-epidemiological examination of construction designs, hygienic, sociological and medico-statistical using licensed StatSoft STATISTICA (v. 5.5), Excel programs.

${ }^{8}$ Pavlenko N.P. Hygienic issues of standardization of volume-planning indicators of construction of general educational institutions in Ukraine and the countries of the European Union. Hygiene of populated areas : Coll. Science. pr. K., 2019. Vip. 68. P. 33-42.

${ }^{9}$ New Ukrainian school. Conceptual principles. High school reform. MES of Ukraine. Kiev, 2016. 40 p.

${ }^{10}$ Order of the Ministry of Education and Science of Ukraine dated March 23, 2018 № 283 "On approval of Methodical recommendations for the organization of the educational space of the New Ukrainian School".

${ }^{11}$ Research of the factors influencing the health of rural and urban schoolchildren studying at secondary educational institutions by sanitary-hygienic parameters / V.M. Machniuk, O.O. Polka, N.P. Pavlenko, V.V. Chorna, G.V. Klimenko, N.M. Tarasova. Hygiene and ecology in state regulation of urban planning / edited by the corresponding member of NAMS of Ukraine N.S. Polky. K. : Publisher : IEC “Medinform”, 2020. P. 114-127. 


\section{Assessment of the provision of the child population of Ukraine with general secondary education institutions}

According to the results of the retrospective analysis of the provision of the children's population of Ukraine with GSEI and in order to determine the proportionality of the availability of places in them to the actual need for the children of primary school age, it was established that the number of schools decreased by $30 \%$ over 30 years, by $678(4.03 \%)$ only during 2017-2018, by 200 schools $(1.3 \%)$ in 2019,246 of them due to their breakdown state and a need in major repairing (241 $(1.4 \%)$ of state and $5(2.9 \%)$ of private ownership). At the same time, the number of pupils has increased by 323 thousand over last three years.

Studying the ratio between the availability of primary schools and the number of children of primary school age, we found a significant discrepancy, so-called "scissors": the annual decrease at the first degree schools and the steady increase in the number of primary school pupils (Fig. 1).

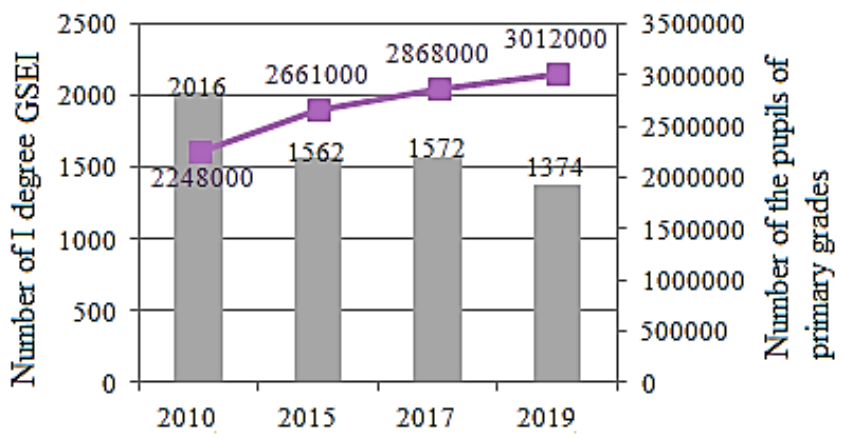

Fig. 1. The ratio of the number of I degree (units) GSEI and the number of children (people) of primary school in Ukraine in 2000-2019

Taking into account that according to the town-planning legislation, the GSEI is a public object and is an obligatory element of service of the population with a location in pedestrian accessibility from the habitation, their construction should be carried out with housing construction in parallel. However, in Ukraine, the principle of proportionality of the construction of new residential buildings and the GSEI has been violated, which leads to the use of schools located at the above regulatory distance and causes their excess capacity. Today, the class size at primary school in Kyiv is from 32 to 43 pupils, in satellite cities - from 34 to 40 pupils, which significantly exceeds the regulated standard. 
Until 2019, there was a tendency to increase the number of first-graders in Ukraine. It can be explained by the introduction of social programs to support the birth rate (since 2011) and the mandatory introduction of the beginning of the education for the children from 6 years of age at the legislative level. Thus, in Kyiv, an increase in the number of first-graders is predicted by at least 1.000 per year (Fig. 2).

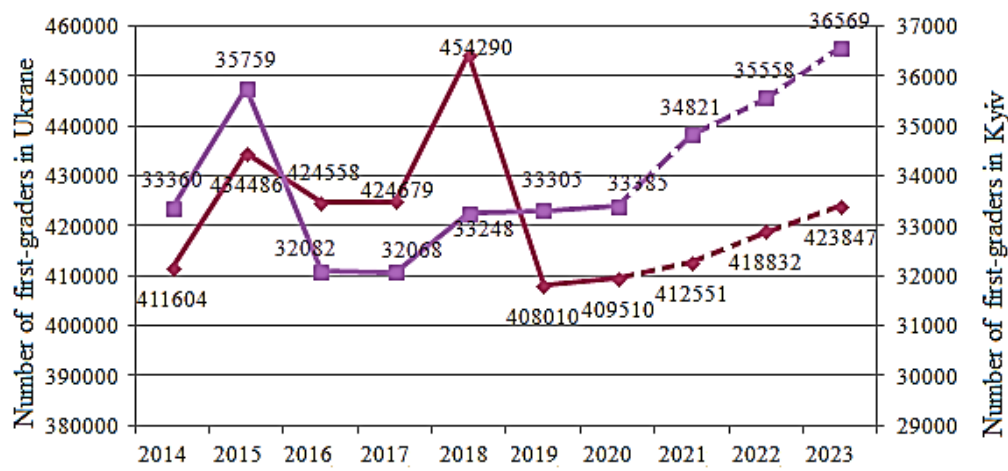

Fig. 2. Dynamics of the number of first-graders of the GSEI (taking into account the predicted parameters) in Ukraine and Kyiv

\section{Comparative characteristics of the national sanitary, educational and} town-planning legislation of Ukraine with some countries of the world

The next aim of this study was to study the regulatory framework of sanitary, educational and town-planning legislation of Ukraine in comparison with the neighbour European countries (UK, Ireland, Finland, England, Scotland, Germany, Austria, Poland) that are in a similar light climate zone, which was important for design and construction of the GSEI in sanitary-epidemiological aspect.

When comparing the standards of the territory of school playgrounds for primary school pupils, this parameter was found to be 2-4-fold smaller in Ukraine than in other European countries.

At the analysis of domestic standards on the division of land of the GSEI into functional zones, the area of the functional zones, not involved in the educational program, in particular, training-research zone from $12 \%$ to $18 \%$ and pre-service training one from $4 \%$ to $7 \%$, was found to increase with an increase of school capacity (Fig. 3). 
for one parallel (12 grades, 360 pupils)

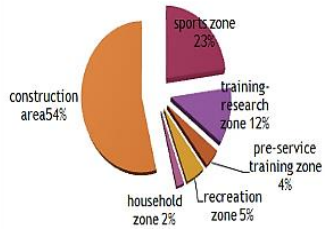

for two parallels (24 grades, 720 pupils)

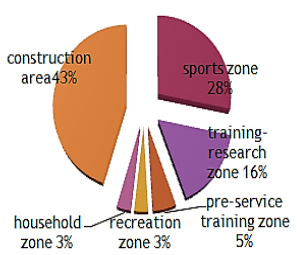

for three parallels (36 grades, 1080 pupils)

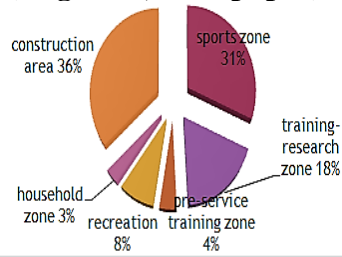

Fig. 3. The share of the area of functional zones for the GSEI of I-III degrees taking into account different capacity (number of parallels)

This leads to the compaction of the recreation zone, artificial congestion of children, which creates an increase in psychogenic load and increase of the incidence of contagious infections, including COVID-19, and is epidemiologically dangerous (Fig. 4).

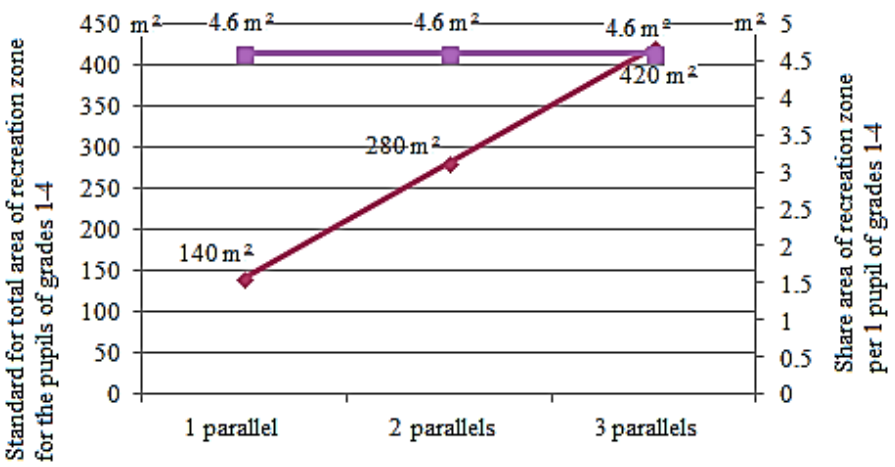

Fig. 4. Standards of the total area of the recreation zone for the pupils of the grades 1-4 and the area of the recreation zone per 1 pupil of grades 1-4 of the GSEI

The lack of the playing and sports grounds in the GSEI leads to a low level of motor activity and deterioration of the pupils health and a decrease of their efficiency, therefore. According to the WHO criteria, the optimal motor activity of the children of school age should make up 60 minutes of the exercises of physical load of high intensity every day. By the results of performed research, the motor activity of $44-50 \%$ of the pupils complies with these criteria. Besides, only one third of all pupils are engaged in physical exercises only in physical training lessons, which causes an increase of the number of posture disorders and cumulation of fatiguability. 
At the new construction of training-practical and training-research zones should be assumed only by the individual designs of the construction (by separate task for design) taking into account the GSEI specialization.

In the European countries, the school territory is equipped with sports equipment and equipment for games in accordance with the functional purpose and age of children according to the requirements of the EU EN1176 Playground Equipment Standard. Based on the results of the European experience, withinvthe harmonization of the Ukrainian legislation with the European one, we have developed the first version of the national document - Improvement and Decoration of School Playgrounds State Standard of Ukraine (DSTU)).

During the research we conducted a sanitary-epidemiological assessment of the individual designs of the GSEI construction ( 26 urban and 16 rural) by 48 criteria for planning organization of the land area and by 81 parameters for training premises in the building.

\section{Hygienic assessment of the features of modern architectural and planning decisions of general secondary education institutions}

According to the results of the study, it was found that the sanitary regulatory distances be observed in $91 \%$ of rural school designs and not observed in $29 \%$ of urban ones. Land area met the standard in $64 \%$ of rural and $33 \%$ of urban schools. There were no functional zones in $24 \%$ of urban school construction design due to the shortage of land area, i.e. every fourth surveyed school did not have sufficient land allocation.

The insolation both school building and its territory is an important parameter that affects the health of pupils and the formation of townplanning situation. The territory of playgrounds was found not to be insolated at all in $14 \%$ of urban school projects during the day.

Every third urban school (29\%) had a shortage of training premises and, as a result, operated with a class size that on average exceeded the standard by $23 \%$.

When studying the insolation of training premises in $17 \%$ of urban school projects, the parameter did not meet regulatory requirements.

The study of the parameters of air change of the classrooms of typical area and height $\left(52 \mathrm{~m}^{2}, 3.3 \mathrm{~m}\right.$, respectively) with natural ventilation and their actual size 35-40 pupils (at standard 30) demonstrated that the standards of air change during training were not observed and was $9 \mathrm{~m}^{3} / \mathrm{h}$ per child (if standard is $16 \mathrm{~m}^{3} / \mathrm{h}$ ), which didn't not ensure air quality in the classroom and affected the deterioration of well-being and decrease in the efficiency of the pupils. We have proved that in order to comply with the standard parameters of air quality in the classroom with a typical area of $52 \mathrm{~m}^{2}$ and $3.3 \mathrm{~m}$ height with a class size of 30 pupils (standard of the MES) it is 
necessary to equip the classrooms with mechanical ventilation with air change rate $30 \mathrm{~m}^{3} / \mathrm{h}$ per child $(\mathrm{K}=4.17 \mathrm{1} / \mathrm{h})$, which coincides with a similar standard parameter of the European Union.

According to our calculations for the introduction of the innovations for primary school pupils at the training at the New Ukrainian School, a use of one classroom (50-56 $\mathrm{m}^{2}$ typical area and $3 \mathrm{~m}$ height) by eight directions of zoning and its arrangement of single desks when the class size is 30 and more pupils leads to a shortage of class area of $16 \%$, violation of the use of school areas, which worsens the sanitary conditions, increases the psychological load, causes "school" pathology - disorders of posture, vision and injuries in children.

The standards for left-hand lighting of working places, introduced to prevent the occurrence of pathology of the visual organs, are met only for a third of the pupils.

In studied designs of the construction of foreign schools, a block system is a typical solution for junior grades, this system provides $2-4$ rooms with recreations which are used alternately to comply with sanitary and epidemiological conditions.

According to the parametric calculations, in order to create the safe stay conditions for children, we have substantiated planning decisions on the row location of desks with the passages among them and a new minimum class size of 15 pupils for the needs of the NUS with 8 functional zones on the basis of existing typical classrooms with natural air change (Fig. 5).

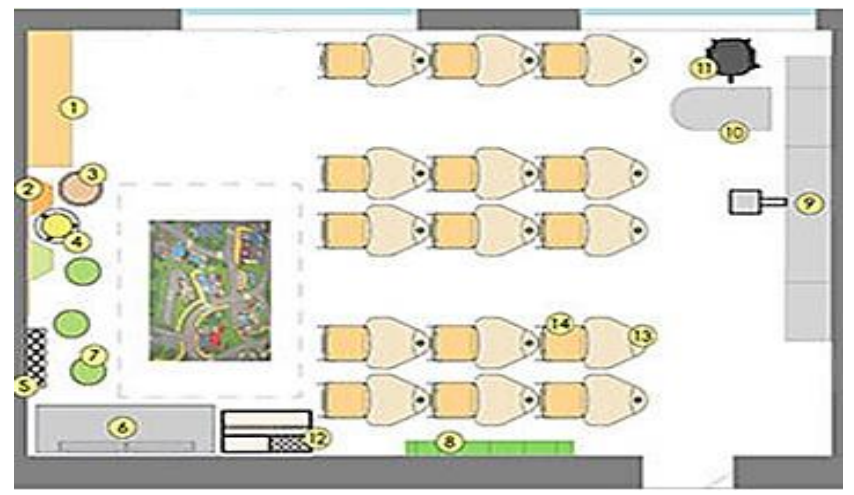

Fig. 5. New planning solution of the educational premises at the NUS, with a new class size of 15 pupils, with the arrangement of functional areas and single desks on the basis of a typical class of existing GSEI

According to the results of the expert assessment of the construction designs of urban and rural GSEI, it was found that the insolation of school 
grounds met the standard in $87 \%$ of rural and $50 \%$ of urban GSEI. $9 \%$ of rural and 33\% of urban GSEI had worsened insolation conditions by $0.5-1$ hour less than the standard. In other cases, the insolation was 2 -fold less than the standard value (Fig. 6).

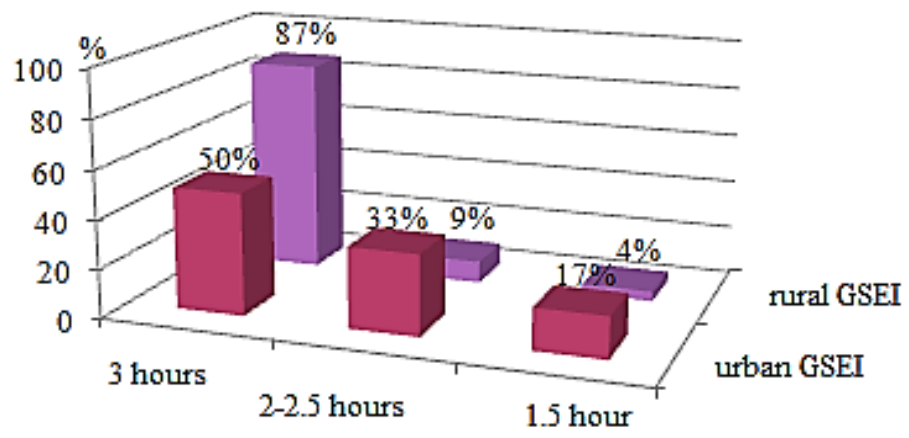

Fig. 6. The share of school grounds of urban and rural GSEI with different duration of insolation, \%

Examining the general use of school grounds for outdoor stay of the children, it was determined that most of them $(67-80 \%$ of cases) were used by the pupils after school time, i.e. in extracurricular time. While studying at school, only a third of the first-graders and a fifth of 4-th graders use the school ground during breaks, which eliminates the positive effect of outdoor physical activity on their health and is not an effective parameter of the use of town-planning territory (Fig. 7). Therefore, as an additional measure, we have substantiated a new standard for the area of the playgrounds in the residential area of $2.0 \mathrm{~m}^{2}$ per child to replace existing $0.2 \mathrm{~m}^{2}$, which indirectly, due to increased outdoor motor activity of the children of primary school age in extracurricular hours, will help prevent the disorders of the musculoskeletal system.

There is a negative dynamics of 2 -fold reduction of the number of children (from $66 \%$ in the first grade to $32 \%$ in the fourth one), which have the standard duration of walks. At the same time, there is an increase of the number of the pupils who stay outdoor for less than 1 hour, i.e. 3.5 -fold lower than the standard (in the 1-st grade $-13 \%$, in the 2 -nd grade $-22 \%$, in the 3-rd grade $-27 \%$, in the 4 -th grade $-34 \%$ ) (Fig. 8). 


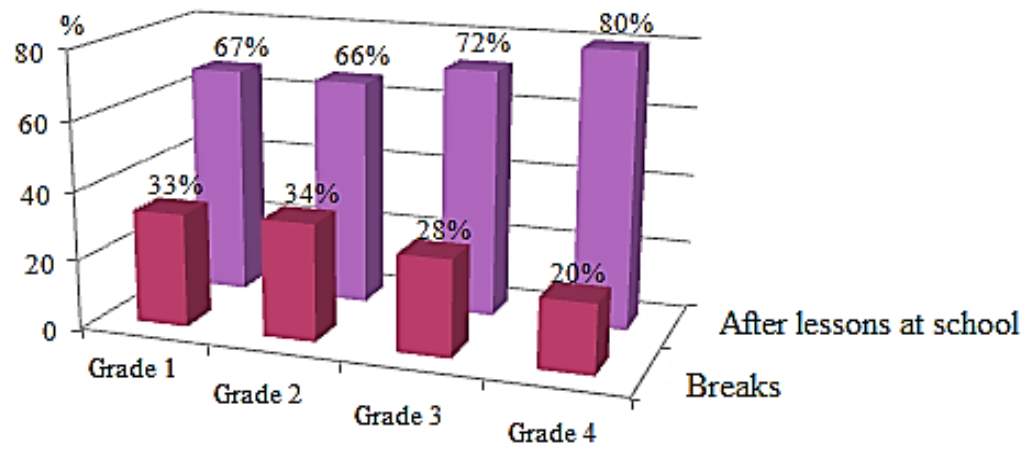

Fig. 7. Share of the number of pupils of urban GSEI with different use of school grounds: during breaks and after lessons at school, \%

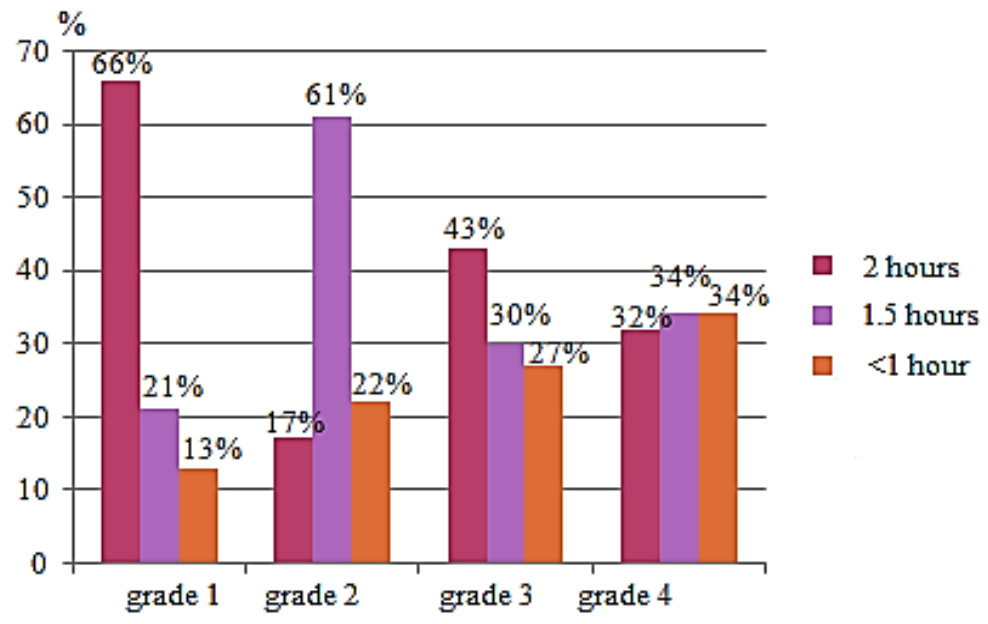

Fig. 8. Share of the number of the pupils of urban GSEI with different duration of walks during breaks, \%

Thus, a share of the first-graders, that were in the open air in a standard time, decreased in the fourth grade $(\mathrm{p}<0,001)$. 


\section{Determining the influence of direct and indirect indicative indicators of architectural and planning decisions of GSEI}

on the formation of deviations in the health and psycho-emotional state of primary school students

To conduct a study of the daily routine of the pupils, we have identified standard and actual architectural-and-planning parameters (Table 1).

Table 1

\begin{tabular}{|c|c|c|c|c|c|c|c|c|}
\hline & \multicolumn{8}{|c|}{ Architectural-and-planning parameters } \\
\hline & 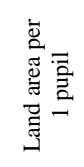 & 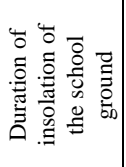 & 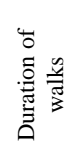 & 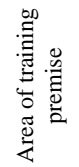 & 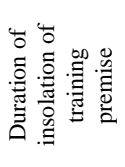 & 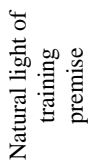 & 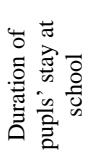 & 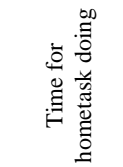 \\
\hline $\mathrm{S}$ & $23 \mathrm{~m}^{2}$ & $3 \mathrm{~h}$ & $2.5 \mathrm{~h}$ & $2.2 \mathrm{~m}^{2}$ & $3 \mathrm{~h}$ & $1.5 \%$ & $5 \mathrm{~h}$ & $30-45 \mathrm{~min}$. \\
\hline A & $13.8 \mathrm{~m}^{2}$ & $1.89 \mathrm{~h}$ & $0.75 \mathrm{~h}$ & $1.2 \mathrm{~m}^{2}$ & $1 \mathrm{~h}$ & $1 \%$ & $8 \mathrm{~h}$ & $2.5 \mathrm{~h}$ \\
\hline $\mathrm{bS}$ & $60 \%$ & $63 \%$ & $30 \%$ & $56 \%$ & $41 \%$ & $69 \%$ & $160 \%$ & $500 \%$ \\
\hline
\end{tabular}

$S-$ standard, A-actual, bS-below standard.

The replacement of outdoor active motor games with a "sitting" conditions by increasing the duration of homework doing and attending extracurricular activities with static conditions was found at a detailed study of the daily routine of the pupils in grades 1-4 in 30\% of the pupils. According to the expert opinion of the respondents (the hygienists), the pupils were at school for 8 hours, i.e. the working day of the adult, which has been also confirmed by the results of the survey of most parents (84-93\% of cases).

When studying the compliance of insolation with the standards in the educational premises of studied GSEI, it was found that its duration corresponded to the standard in $73 \%$ of the premises for the first grades and decreased in $62 \%$ of the premises for the fourth ones in rural schools. In urban GSEI with the dense building conditions, the first grade premises had unsatisfactory insolation (less than 1 hour) in a third of cases, which was extremely insufficient for the effectiveness of the biological effect of insolation (Fig. 9).

According to the Report on the Environmental Factors Affecting the Health of the Population State Statistical Form f.18 we studied retrospectively the actual state of the space of training premises for primary school pupils in experimental urban (in Kyiv) and rural GSEI by physical factors (Fig. 10, 11). 


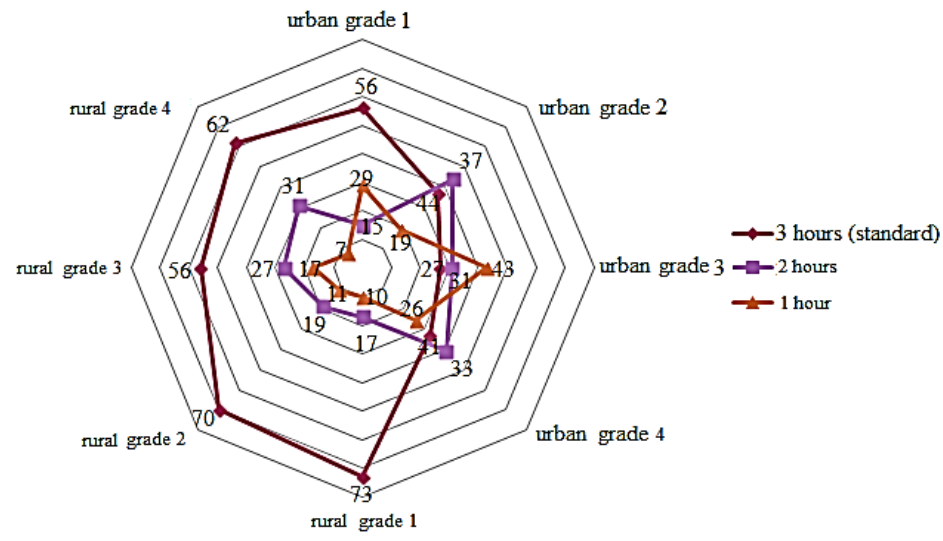

Fig. 9. The share of the number of training premises in urban and rural GSEI with different duration of insolation, \%

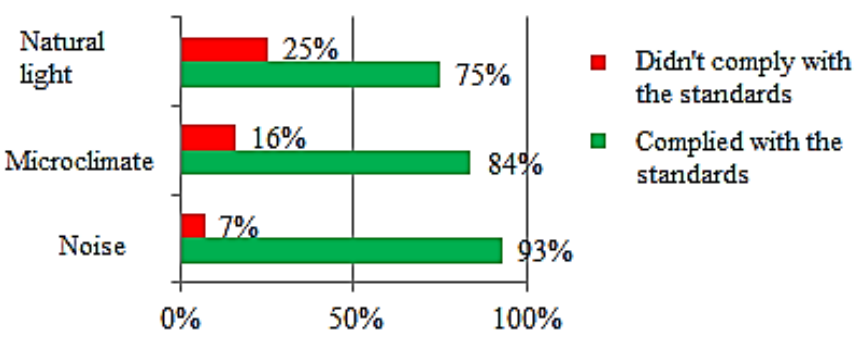

Fig. 10. Parameters of natural light, microclimate and noise in the premises of the GSEI in Kyiv, \%

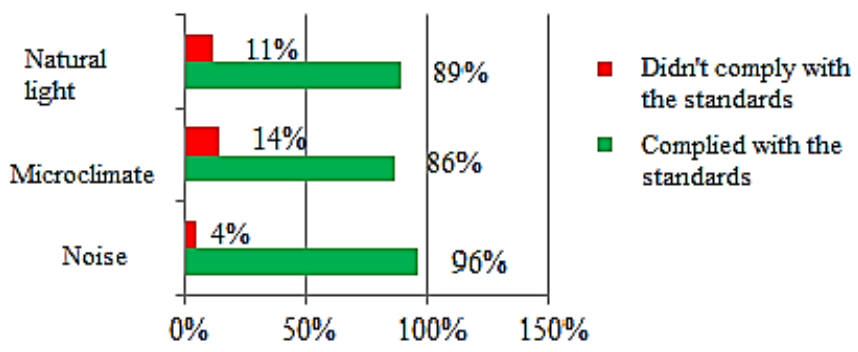

Fig. 11. Parameters of natural light, microclimate and noise in the premises of rural GSEI, \% 
The obtained findings show 1.8-2.3-fold excess of the number of actual studies that did not meet the standards for natural light and noise in urban schools compared to rural ones, and is explained by dense urban construction conditions. This prompted us to investigate a compliance with the standards of architectural-and-planning decisions in the urban GSEI.

The results of the survey of the parents of the pupils in grades 1-4 on the impact of the GSEI dense conditions on indirect parameters of architectural -and planning -decisions: the area of training premises, the duration of its insolation, the distance from school to adjacent buildings, the duration of the stay of the pupils at school and time for walk showed that there was a deterioration in wellbeing and reduced efficiency at the incompliance with the parameters of the standards in schoolchildren. Thus, in case of insufficient area for training, the health of $26.3 \%$ of the pupils was registered as unsatisfactory ( $\mathrm{rS}<0.78, \mathrm{p}$ $<0.001$ ), and $18.75 \%$ of the pupils ( $\mathrm{rS}<0.88, \mathrm{p}<0.001$ ) had a deterioration in their efficiency. There is a direct relationship between dense conditions (shortage of insolation duration of school premises, lack of outdoor walks, the pupil's stay at school above standard - for 8 hours) and deterioration of well-being and reduced efficiency $(\mathrm{p}<0.001)$ (Table 2).

Table 2

\section{Dependence of psychophysiological state (well-being and efficiency) of the pupils of grades1-4 at urban GSEI on dense building conditions (according to indirect parameters of architectural-and-planning decisions)}

\begin{tabular}{|c|c|c|c|c|c|c|c|}
\hline \multirow{2}{*}{ Parameters } & & \multicolumn{3}{|c|}{ Well-being } & \multicolumn{3}{c|}{ Efficiency } \\
\cline { 2 - 8 } & $\begin{array}{c}\text { insuf- } \\
\text { ficient }\end{array}$ & $\begin{array}{c}\text { suf- } \\
\text { ficient }\end{array}$ & good & $\begin{array}{c}\text { insuf- } \\
\text { ficient }\end{array}$ & $\begin{array}{c}\text { suf- } \\
\text { ficient }\end{array}$ & good \\
\hline $\begin{array}{c}\text { Area of } \\
\text { training } \\
\text { premise per } \\
\text { 1 pupil, m }\end{array}$ & share, \% & 26.3 & 48.6 & 25.10 & 18.75 & 43.01 & 38.24 \\
\cline { 2 - 8 } & $\begin{array}{c}\text { coef.cor.r } \\
\text { S }\end{array}$ & 0.78 & 0.80 & 0.85 & 0.88 & 0.86 & 0.88 \\
\hline $\begin{array}{c}\text { Duration of } \\
\text { insolation of } \\
\text { training } \\
\text { premise }\end{array}$ & share,\% & 32.94 & 27.53 & 39.53 & 26.73 & 31.68 & 41.58 \\
\cline { 2 - 8 } & $\begin{array}{c}\text { coef.cor.r } \\
\text { Duration of } \\
\text { pupils' stay } \\
\text { at school }\end{array}$ & 0.45 & 0.42 & 0.50 & 0.76 & 0.81 & 0.80 \\
\cline { 2 - 8 } & share, $\%$ & 26.18 & 30.07 & 43.75 & 13.20 & 26.73 & 60.07 \\
\hline $\begin{array}{c}\text { Duration of } \\
\text { walks }\end{array}$ & share, $\%$ & 17.91 & 31.25 & 50.84 & 10.56 & 27.72 & 61.72 \\
\cline { 2 - 8 } & $\begin{array}{c}\text { coef.cor.r } \\
\mathrm{S}\end{array}$ & 0.67 & 0.6 & 0.68 & 0.62 & 0.59 & 0.64 \\
\hline
\end{tabular}


We conducted the observations on the deterioration of visual acuity, posture disorders and signs of scoliotic posture formation under the impact of common sanitary parameters of the GSEI and daily routine of the pupils over four years.

To analyze those findings, the indicative direct and indirect parameters of architectural- and -planning decisions were identified and numerous links between them were established by the changes in pupils' health.

According to medical charts, we have established the close links between direct and indirect parameters of architectural- and- planning decisions, which are the parts of the formation of educational space, and the pathological injuires in primary school pupils in urban GSEI: decrease of visual acuity in 20-23\% of pupils at reduced standards of natural light of the classroom by $69 \%(\mathrm{rS}-0.95, \mathrm{p}$ $<0.001$ ), 5-fold increase of the standard duration of doing homework ( $\mathrm{rS}-0.89$, $\mathrm{p}<0.001$ ), reduction of the standard of the area of the classroom per 1 pupil by $56 \%(\mathrm{rS}-0.91, \mathrm{p}<0.002$ ); posture disorders in $22-33 \%$ of pupils with a decrease in the standards of natural light of school premises by $69 \%(\mathrm{rS}-0.93$, $\mathrm{p}<0.001$ ), reduction of the standard duration of outdoor walks by $30 \%$ $(\mathrm{rS}-0.87, \mathrm{p}<0.002), 1.6$-fold excess of the standard for the duration of pupils' stay in the school premises ( $\mathrm{rS}-0.87, \mathrm{p}<0.001)$; scoliotic posture in $10-17 \%$ of pupils with the underestimation of the standard of duration of outdoor walks by $30 \%(\mathrm{rS}-0,84, \mathrm{p}<0,05), 5$-fold increase of the standard of duration of homework doing $(\mathrm{rS}-0,79, \mathrm{p}<0.05)$, reduction of the standards of natural light of school premises by $69 \%(\mathrm{rS}-0.87, \mathrm{p}<0.05), 1.6$-fold excess of the standard of the duration of the stay of the pupils at school $(\mathrm{rS}-0.76, \mathrm{p}<0.05)$ (Table 3$)$. 
Table 3

Formation of pathological injuires (decreased visual acuity, posture disorders, scoliotic posture) in the primary school pupils of urban GSEI in dense building conditions (according to direct parameters of architectural- and-planning decisions)

\begin{tabular}{|c|c|c|c|c|c|c|c|c|c|}
\hline 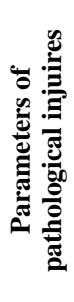 & 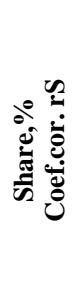 & 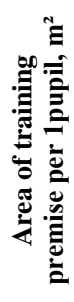 & 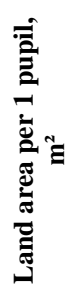 & 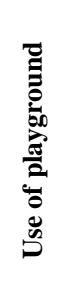 & 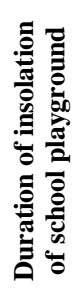 & 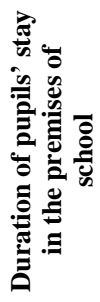 & 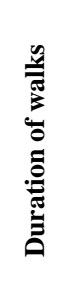 & 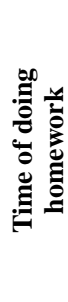 & 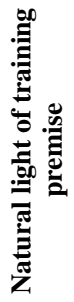 \\
\hline \multirow{2}{*}{ 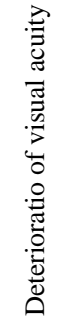 } & 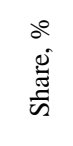 & 17 & 11 & 12 & 18 & 20 & 17 & 19 & 23 \\
\hline & 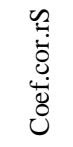 & 0.91 & 0.53 & 0.58 & 0.26 & 0.87 & 0.78 & 0.89 & 0.95 \\
\hline \multirow{2}{*}{ 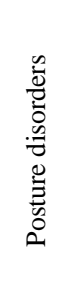 } & 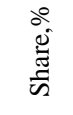 & 22 & 23 & 16 & 6 & 26 & 22 & 16 & 33 \\
\hline & $\begin{array}{l}\mathscr{1} \\
\dot{0} \\
\dot{0} \\
\dot{0} \\
\dot{0}\end{array}$ & 0.78 & 0.81 & 0.84 & 0.2 & 0.9 & 0.87 & 083 & 0.93 \\
\hline \multirow{2}{*}{$\begin{array}{l}0 \\
\Xi \\
0 \\
0 \\
0 \\
0 \\
0 \\
: 0 \\
0 \\
0 \\
\tilde{D}\end{array}$} & 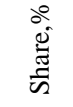 & 10 & 4 & 9 & 2 & 16 & 12 & 10 & 17 \\
\hline & $\begin{array}{l}\tilde{L} \\
\dot{0} \\
\dot{0} \\
\dot{0} \\
\dot{0}\end{array}$ & 0.76 & 0.47 & 0.74 & 0.21 & 0.76 & 0.84 & 0.79 & 0.87 \\
\hline
\end{tabular}




\section{Substantiation of a set of preventive measures for hygienic provision of optimal living conditions for primary school students in GSEI}

According to our findings, to prevent "school" diseases in the primary school pupils, formed under the influence of unsatisfactory direct and indirect hygienic parameters of architectural- and -planning decisions during their training at GSEI (they are essentially occupational diseases), we have substantiated a set of measures and proposals for various departments (Ministry of Education and Science, Ministry of Health of Ukraine, Ministry of Regional Development) to improve existing and create new hygienic indicative criteria for the design of new and reconstruction of existing urban and rural GSEI (Fig. 12).

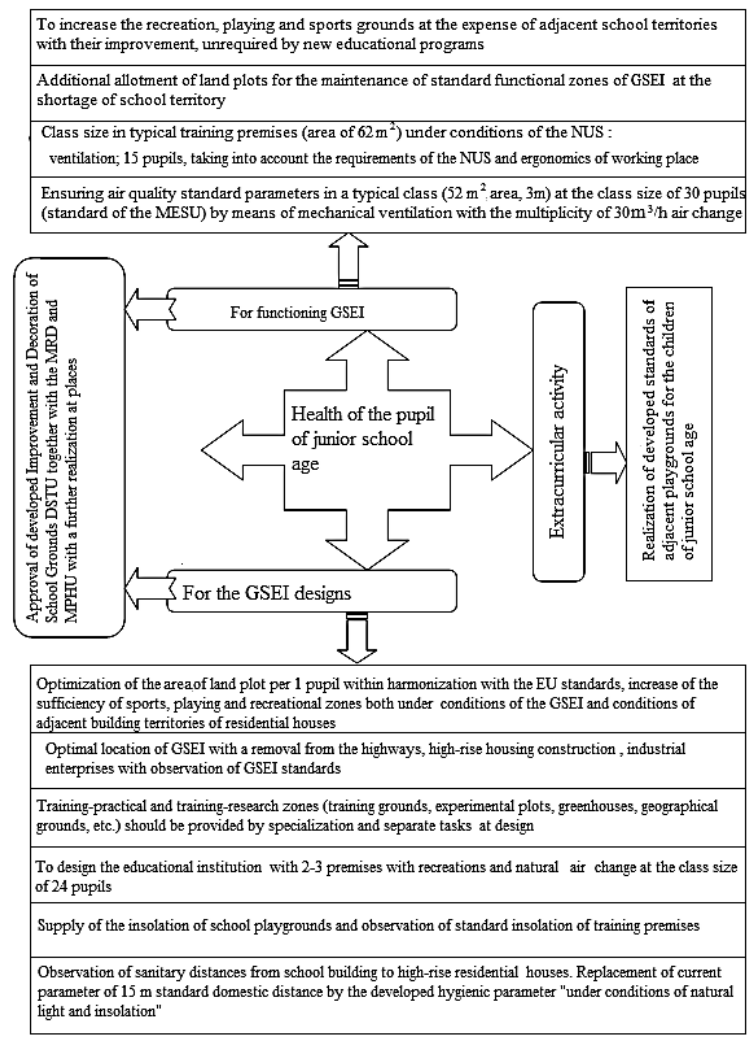

Fig. 12. A set of preventive measures to prevent "school" diseases of primary school pupils at the design of new and reconstruction of existing urban and rural GSEI 


\section{CONCLUSIONS}

1. The network of schools was established to decrease by $30 \%$ (1990 - 21.8 thousand in 2018 - 16.2 thousand) in Ukraine for the last 30 years, while the number of the pupils of primary school age increased by $34 \%$ for the last 10 years $(2009-224800,2019-301200)$. There is a disproportion in the housing construction and the GSEI, which causes additional load on the existing fund of schools $-26.7 \%$ of urban and $4.5 \%$ of rural GSEI, working in 1.5-2 shifts, which complicates their compliance with sanitary and anti-epidemic requirements.

2. The area of primary school playgrounds was found to be $2.3-4$-fold smaller in Ukraine than in Europe. According to the current regulations, the requirements for the arrangement and equipment for playing and recreation zones (sports equipment and facilities according to the age of children) for primary school pupils in Ukraine are not provided, which makes these areas uninteresting and inefficient for the pupils. In this regard, we have developed a draft of national document -- the State Standard of Ukraine (DSTU) "Improvement and Equipment of School Playgrounds" with the elements of implementation of the requirements of the EU standards.

3. $24 \%$ of the designs of the urban GSEI was established not to be provided with functional zones for junior schoolchildren, which required the allocation of additional land plots. Sanitary standard distances from adjacent buildings to schools were not observed in $29 \%$ of urban GSEI, which is 3 -fold higher than in rural GSEI ( $\mathrm{p}<0.001$ ).

The share of the pupils in urban schools who were outdoors in the standard time decreased from $66 \%$ in the first grade to $32 \%$ in the fourth one ( $p<0.001)$ and, on the contrary, increased the percentage of children who walked less than 1 hour (twice less than standard): 1-st grade - 13\%, 2-nd grade $-22 \%, 3$-rd grade $-27 \%$, 4-th grade $-34 \%(\mathrm{p}<0.001)$.

4. According to the daily routine of the examined children of primary school age under school conditions, the school playground was established to be used during breaks only by $33 \%$ of children of the 1 -st grade and $21 \%$ - the 4th grade that is not enough for positive effect of outdoor physical activity on the health of the pupils. In extracurricular time, the adjoining playground of a residential building is used by the first-graders in $67 \%$ of cases, and by the fourth-graders in $79 \%$, which scientifically substantiates the increase of its size from $0.2 \mathrm{~m}^{2}$ to $2.0 \mathrm{~m}^{2}$ per child of primary school age and introduced them at places.

5. The presence and probability of the relationship between dense townplanning conditions and shortcomings of architectural- and- planning solutions in the GSEI according to the following parameters: area of school premises, duration of insolation, time of the pupils' stay at school, duration of walks and psychoemotional state $(\mathrm{p}<0,001)$ were proved. The reliable 
correlations of a moderate and strong degree between architectural -and -planning decisions that did not correspond to the standard values by direct parameters: the area of the classroom, the level of natural light in the classroom, the duration of homework doing, the duration of outdoor walks, the duration of pupils' stay at school, and parameters of pathological injuires of the organs of vision $(\mathrm{rS}-0.95)$ and spine $(\mathrm{rS}-0.84)$ were revealed.

In order to prevent "school" diseases among primary school pupils, which are formed under the influence of unsatisfactory direct and indirect hygienic parameters of architectural planning decisions during their training under conditions of the GSEI, a set of measures and proposals for the Ministry of Education and Science, Ministry of Health of Ukraine, Ministry of Regional Development has been substantiated to improve existing and create new hygienic indicative criteria for designing new and reconstruction of existing urban and rural GSEI.

\section{SUMMARY}

The research allowed:

- to reveal a reduction of the number of schools by $30 \%$ for the last 30 years and a growth of the number of pupils only for the last three years by 323 thousand, which sharply increased the load on existing schools at the retrospective analysis of the maintenance of children's population of the general secondary education institutions (GSEI) of the I, I-II, I-III degrees;

- to identify the violations of the principle of proportionality of the construction of new residential buildings and required number of the GSEI for the residents of new buildings by which the new GSEI are not built, that leads to the use of schools located at the above standard distance and causes their excess capacity;

- to establish that the standard of the territory of school playgrounds for the pupils of primary school age is 2-4-fold less in Ukraine than in other European countries;

- to establish that sanitary standard distances between the educational institution and adjacent residential and public buildings were observed in $91 \%$ of rural school designs, while in urban ones only in $71 \%$, which caused a compaction of the residential areas;

- to determine the absence of need in the territories of training-practical and training-research zones (training grounds, research sites, greenhouses, geographical grounds, etc.) in modern educational programs and to recommend their use in sports, playing and recreation zones in functioning GSEI;

- to substantiate a need to take into account the territories of training and- research and training- and- practical zones in design of specialized GSEI; 
- to determine that every third urban school functioned with the excess of the standard parameter of class size by more than $23 \%$, which leads to congestion of the pupils and deterioration of sanitary and vital function conditions at GSEI;

- to establish that standards for natural air exchange during training are not observed and make up $9 \mathrm{~m}^{3} / \mathrm{h}$ per child $\left(16 \mathrm{~m}^{3} / \mathrm{h}\right.$ is a necessary standard), which does not ensure air quality in the classroom and affects the deterioration of well-being and decrease of the efficiency of the pupils;

- to establish that there is a shortage of the area for the training premises of primary school in $16 \%$ to implement the conception of the New Ukrainian School in functioning GSEI;

- to identify the replacement of outdoor active motor games with the static conditions ("sitting" conditions) due to the increase of the duration of homework doing and attendance of extracurricular circles with passive activities in the daily routine of the pupils of grades $1-4$ in $30 \%$ of cases;

- to establish the existence of close relationships between direct and indirect parameters of architectural-and-planning decisions, which are the part of the formation of educational space, and the determinants of health of primary school pupils;

- to substantiate a set of preventive measures and proposals for the Ministry of Education and Science (MES), the Ministry of Health (MHU), the Ministry of Regional Development (MRD) in order to prevent the development of "school" occupational diseases of primary school pupils at the design stage of new and reconstruction of existing GSEI.

\section{REFERENCES}

1. Serdyuk A.M., Polka N.S., Makhnyuk V.M. Modern problems of hygiene of planning and building of settlements (normative-legal regulation) : monograph. K. : MIC "Medinform”, 2014. 174 p.

2. Mental capacity, educational load and way of life of modern schoolchildren: hygienic aspects : monograph / N.S. Polka, S.V. Gozak, O.T. Elizarova, A.M. Parats, T.V. Stankevich, I.O. Kalinichenko, G.L. Zaikina, G.O. Latina ; ed. N.S. Polki, S.V. Gozak. Kyiv : Medinform, 2018. 214 p. P. $185-210$.

3. Pavlenko N.P., Makhnyuk V.M., Gozak S.V. Sanitary and hygienic conditions for children in existing and projected secondary schools of Ukraine. Hygiene of populated places : collection. Science. pr. K., 2017. Vip. 66. P. 228-235.

4. "Hygiene and ecology in state regulation of urban planning". Edited by the corresponding member of NAMS of Ukraine N.S. Polky / V.M. Machniuk, V.G. Hopperia, O.O. Polka, N.P. Pavlenko, G.V. Ocheretyana. Publisher : IEC "Medinform", 2020. 170 p. 
5. Demographic and social statistics. Population and migration. State Statistics $\quad$ Service. $2020 . \quad$ URL: http://www.ukrstat.gov.ua/operativ/menu/menu_u/ds.htm.

6. Demographic trends in Ukraine. URL: http://rb.com.ua/rus/marketing/tendency/8227/.

7. Demographic and social statistics / Education. URL: http://www.ukrstat.gov.ua/operativ/menu/menu_u/osv.htm.

8. Pavlenko N.P. Hygienic issues of standardization of volume-planning indicators of construction of general educational institutions in Ukraine and the countries of the European Union. Hygiene of populated areas : Coll. Science. pr. K., 2019. Vip. 68. P. 33-42.

9. New Ukrainian school. Conceptual principles. High school reform. MES of Ukraine. Kiev, 2016. 40 p.

10. Order of the Ministry of Education and Science of Ukraine dated March 23, 2018 № 283 "On approval of Methodical recommendations for the organization of the educational space of the New Ukrainian School".

11. Research of the factors influencing the health of rural and urban schoolchildren studying at secondary educational institutions by sanitaryhygienic parameters / V.M. Machniuk, O.O. Polka, N.P. Pavlenko, V.V. Chorna, G.V. Klimenko, N.M. Tarasova. Hygiene and ecology in state regulation of urban planning / edited by the corresponding member of NAMS of Ukraine N.S. Polky. K. : Publisher: IEC "Medinform", 2020. P. 114-127.

\section{Information about the authors: Makhniuk Valentyna Myhailivna,} Doctor of Medical Sciences, Senior Researcher, Doctor of the Highest Qualification Category in the Specialty "General Hygiene",

Head of the Laboratory for Hygiene of Planning and Construction of Settlements

O. M. Marzeiev Institute for Public Health of the National Academy of Medical Science of Ukraine 50, Popudrenka str., Kyiv, 02000, Ukraine

Pavlenko Nataliya Pavlivna, Candidate of Biologycal Sciences, Senior Research at the Laboratory for Hygiene of Planning and Construction of Settlements O. M. Marzeiev Institute for Public Health of the National Academy of Medical Science of Ukraine 50, Popudrenka str., Kyiv, 02000, Ukraine 